Available online at

http://www.anpad.org.br/bar

BAR, Curitiba, v. 7, n. 1, art. 5,

pp. 79-97, Jan./Mar. 2010

\title{
The Influence of Coordination Mechanisms on New Product Development in MNC Subsidiaries
}

\author{
Dirk Michael Boehe * \\ E-mail address: dirkMB@insper.org.br \\ Insper Instituto de Ensino e Pesquisa \\ São Paulo, SP, Brazil.
}

\begin{abstract}
This paper investigates the relationship between [MNC] coordination mechanisms and subsidiary new product development [NPD] activities. We focus on two essentially different coordination mechanisms, internal markets and global decision-making autonomy, and argue that both mechanisms are likely to increase a subsidiary's exposure to market forces which, in turn, provides different kinds of incentives for a subsidiary's in-house NPD and NPD outsourcing. We tested our hypotheses using structural equations modeling. The results suggest that internal markets have a positive effect on NPD outsourcing while global autonomy has a positive effect on inhouse NPD. Thus, this study contributes to integrating the internal market construct with the coordination mechanism stream of literature.
\end{abstract}

Key words: multinational corporations [MNC]; global strategy; subsidiary coordination; internal markets; outsourcing.

Received 07 November 2008; received in revised form 10 June 2009.

Copyright (C) 2010 Brazilian Administration Review. All rights reserved, including rights for translation. Parts of this work may be quoted without prior knowledge on the condition that the source is identified.

\footnotetext{
* Corresponding author: Dirk Michael Boehe Insper Instituto de Ensino e Pesquisa, Rua Quatá, 300, Sala 423, São Paulo, SP, 04546-042, Brazil.
} 


\section{INTRODUCTION}

Many Product Development Units [PDUs] of Multinational Corporation [MNC] subsidiaries find themselves in a situation of survival pressure. As headquarters strive to enhance the cost efficiency of their global network of product development sites, minor, duplicated or less well performing PDUs face the risk of being eliminated (Birkinshaw \& Hood, 1998). In response, PDUs may attempt to claim their stake exploiting new market opportunities, both within the MNC, i.e. selling technological services and product development projects to peer subsidiaries, and developing products for external clients beyond the subsidiary's host country market. However, exploiting such market opportunities requires that the MNC use coordination mechanisms which permit and motivate subsidiaries to carry out product development for internal and external global clients.

This paper focuses on such coordination mechanisms, defined as the process of integrating activities dispersed across subsidiaries (Martinez \& Jarillo, 1991); more specifically, focus is on how MNC coordination mechanisms influence subsidiaries' new product development [NPD] activities. Accordingly, this study hypothesizes and tests a model that examines the combined effect of autonomy and internal markets on a subsidiary's new product development activities. Nevertheless, host country related factors that may also influence subsidiaries' NPD activities such as government incentives, local market demand, and the like, are not considered here, due to reasons of space and scope. Accordingly, this study is concerned with the corporate environment, i.e. the headquartersubsidiary and subsidiary-subsidiary relationships, and its potential effect on a focal subsidiary's NPD activities.

Literature on headquarter-subsidiary and subsidiary-subsidiary relationships has primarily examined formal coordination mechanisms, such as centralization of decision-making at main or divisional headquarters, formalization, planning, performance control, and informal mechanisms, such as informal communication, socialization, normative integration, particularly transfer of knowledge, intra-company technology transfer, people, goods and services among MNC units, R\&D co-practice, inter-unit networking, headquarters attention and subsidiary entrepreneurship (Bartlett \& Ghoshal, 1989; Bouquet \& Birkinshaw, 2008; Bouquet, Morrison, \& Birkinshaw, 2009; Fischer \& Behrman, 1979; Foss \& Pedersen, 2002; Frost \& Zhou, 2005; Ghoshal \& Nohria, 1993; Gupta \& Govindarajan, 1991, 1994; Kurokawa, Iwata, \& Roberts, 2007; Martinez \& Jarillo, 1991; Monteiro, Arvidsson, \& Birkinshaw, 2008; Nobel \& Birkinshaw, 1998; Sanna-Randaccio \& Veugelers, 2007; Venaik, Midgley, \& Devinney, 2005). This stream of literature has been mainly concerned with conciliating strong globalization and localization pressures, with decision-making control (autonomy) being the most researched coordination mechanism. However, it does not reflect on competitive or market-like relationships among MNC units as a coordination mechanism.

A second stream of literature directly focuses on such competitive or market-like relationships also known as internal markets (Birkinshaw, 2001; Birkinshaw \& Fey, 2000; Birkinshaw \& Lingblad, 2001, 2005); however, their arguments have rarely been submitted to empirical tests. Moreover, to our knowledge, research has not explicitly addressed the combined influence of different coordination mechanisms on subsidiaries' new product development [NPD] activities.

Thus, by hypothesizing and testing a model which examines the combined effect of autonomy and internal markets on a subsidiary's new product development activities, we attempt to extend theory on coordination mechanisms.

While existing research has focused either on coordination mechanisms in MNCs or on the configuration (in-house vs. outsourcing) of NPD activities, the original contribution of the present study consists in assessing the proposed link between coordination mechanisms (internal and external market pressures) and the configuration (in-house vs. outsourcing) of subsidiary NPD activities.

In the following section, we review the literature and develop our conceptual model exploring the question of how global decision-making autonomy and internal markets may influence subsidiaries' 
new product development [NPD] activities via the exposure to global market forces. The model consists of several testable hypotheses regarding the relationships between the decision-making autonomy construct and the internal market construct on the one hand and in-house and outsourced new product development on the other. After the method section, results from structural equations modeling are presented. Finally, we discuss the contributions of the results to the literature on MNC coordination mechanisms and subsidiary development.

\section{SUBSIDIARY COORDINATION MODEL}

This article is based on the assumption that subsidiary roles may change over time (Birkinshaw, 1996; Birkinshaw \& Hood, 1998). Although many different role typologies have been put forward (e.g. Gupta \& Govindarajan, 1991; Jarillo \& Martinez, 1990; Roth \& Morrison, 1992), a basic characteristic of these typologies is that they differentiate subsidiaries with more important from less important roles in their MNC's global strategy. Examples are the strategic leader or implementer role in Bartlett and Ghoshal's (1986) typology. Having said this, a key concern is how these roles may change: coordination mechanisms determined by headquarters constitute a major instrument of subsidiary role changes (Birkinshaw \& Hood, 1998). As mentioned in the introduction, this study focuses on coordination mechanisms implemented by headquarters, specifically the degree of headquarter control, which is inversely related to subsidiary autonomy, and the extent to which competitive, market-like resource allocation mechanisms are used.

Thus, the basic idea of the model is that headquarters may use two different coordination mechanisms in order to expose its subsidiaries to internal and external market forces which, in turn, will create incentives for different organizational configurations in NPD. Figure 1 below identifies two coordination mechanisms (on the left), internal markets and global autonomy, which are hypothesized to influence two organizational configurations in NPD (on the right), in-house NPD and NPD outsourcing.

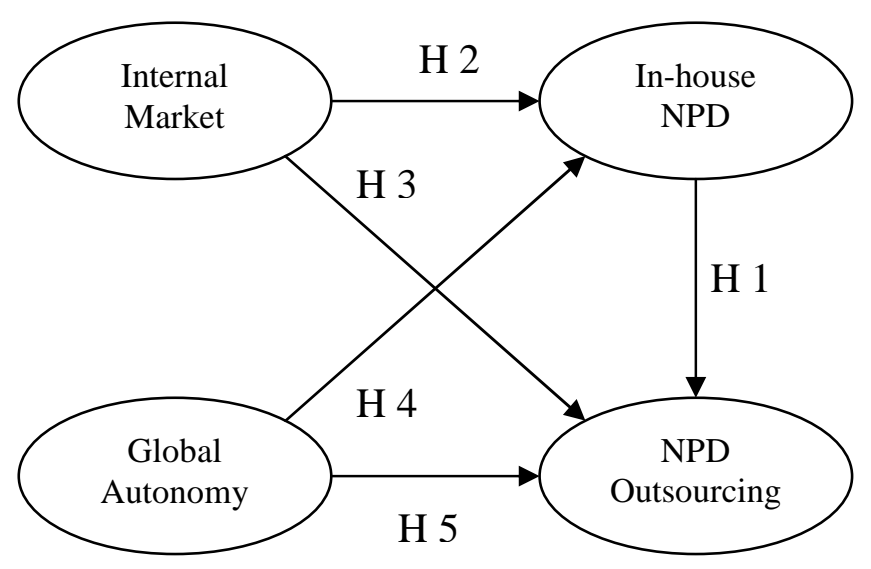

Figure 1: Hypothesized Structural Model

In the next subsection, we describe the two elements of NPD configuration, in-house and outsourcing of NPD, and the relationship between them. Then, we concentrate on the two coordination mechanisms, i.e. the mechanisms which headquarters applies (whether consciously or not) to manage its R\&D network and to expose their units to more or less competition. Finally, all four elements will be integrated into a conceptual model which will be tested subsequently. 


\section{NPD Configuration in Foreign Subsidiaries}

In-house NPD. While there are different concepts of product development processes, operations researchers seem to agree that its heart constitutes the design-build-test cycle (Clark \& Fujimoto, 1991; Wheelwright \& Clark, 1992). During this cycle - which may be repeated until a satisfactory solution is found or until it is abandoned - physical or virtual prototypes are built from a new product design. The prototypes are tested and results fed back into the design stage. This cycle can be complemented by additional stages such as concept development and product planning, process development or applied research. Management may choose to carry out all or only some stages inhouse and to complement in-house activities with externally contracted product development services.

NPD outsourcing. Outsourcing refers to short-term, arms-length relationships between a customer and a supplier, in which the customer passes design, prototype or test specifications to a technical service supplier. Outsourcing has been found to be more common than cooperation in R\&D and is generally carried out under the following conditions: (a) it has to be cost effective, (b) it must not threaten the firm's competitive advantage and (c) various substitutable sources of outsourcing must be available (Narula, 2001).

Whether outsourcing and in-house product development activities are related is questionable from a theoretical point of view: whereas a transaction cost economics perspective would suggest that inhouse NPD (hierarchy) and NPD outsourcing (market transaction) are discrete structural alternatives (Williamson, 1991), they may be seen as complementary from a resource-based perspective (Veugelers \& Cassiman, 1999).

Outsourcing may be undertaken due to a lack of qualified internal resources and capabilities in areas that complement the firm's in-house core activities. Firms focussing on their core competences limit their in-house NPD to what they know how to do best and outsource what third parties can do more efficiently and at a lower cost. Based on the corporate technology profile framework proposed by Granstrand, Patel and Pavitt (1997), firms tend to opt for outsourcing of NPD in areas where their technological competences are low (called background or marginal competences). Conversely, they carry out in-house product development in areas where their competences are high (called distinctive and niche competences) (Narula, 2001).

Similarly, outsourcing may be used for complementary routine-like activities, i.e. for activities requiring resources and capabilities that are not valuable or rare. The resource-based view [RBV] is particularly useful for identifying resource and capability gaps as well as for distinguishing between core and non core activities; thus the RBV may help to identify outsourcing needs and opportunities (Espino-Rodríguez \& Padrón-Robaina, 2006). Therefore, complementarity of resources is a key motivation for outsourcing: drawing on a literature review on outsourcing from the resource-based view of the firm, outsourcing is found to enhance firm performance, "because it provides firms with access to complementary resources of a higher quality and lower costs than those developed in-house" (Espino-Rodríguez \& Padrón-Robaina, 2006, p. 64).

Empirical studies have found that the likelihood of combining in-house NPD with NPD outsourcing depends on firm size: while smaller firms tend to opt for either or strategies, larger firms tend to combine both forms of innovation (Veugelers \& Cassiman, 1999) as they probably have sufficient resources at their disposal to identify, coordinate and control the fulfilment of contracts. Furthermore, NPD outsourcing is also said to be preferred when projects are of low duration, low geographical scope and when they involve a low number of partners and technologies (Croisier, 1998) as this would keep information, coordination and control costs low. Technological capabilities and industry effects are further factors that may possibly influence the propensity to outsource. Firms that develop cuttingedge technologies could be less prone to outsource, since there may be fewer potential outsourcing partners with sufficient absorptive capacity available than in areas more distant from the technological frontier. They may also be more concerned with property rights protection and therefore keep more activities in-house than low technology firms. Veugelers (1997) found several statistically significant industry effects when analyzing the relationship between in-house R\&D and external technological 
linkages. However, even in high technology fields, many firms are probably in a position to separate cutting-edge core from routine-like non-core activities.

Having said this, we argue that an increase of demand for NPD may prompt an increase of outsourced product development activities. Specifically, the decision to increase the NPD activities of a product development unit is likely to trigger a series of decisions on which activities to be outsourced and to be kept in-house. As explained above, issues to be considered in these decisions are related to the distinction between core and non-core activities, specialized and routine activities and protection of property rights, among others. As the size of internal product development and managerial capacity is limited in the short run (due to time-consuming hiring, training and infrastructure investments), firms are expected to cover additional product development demand by outsourcing. Hence, we posit that:

\section{Hypothesis 1. In-house NPD is positively related to NPD outsourcing.}

\section{MNC Coordination Mechanisms}

Coordination mechanisms may influence both in-house NPD and NPD outsourcing, exposing the subsidiary to stronger or weaker market forces. In this section, we discuss two coordination mechanisms; first, the degree of market-like internal competition among product development units for project allocation by peer subsidiaries and headquarters; second, subsidiary autonomy as regards decision-making about initiating product development for and launching new products onto global markets. As suggested by previous MNC research (Birkinshaw, 1997; Birkinshaw \& Fey, 2000; Paterson \& Brock, 2002; Young \& Tavares, 2004), both mechanisms are essential in order to advance understanding of MNC coordination. Both coordination mechanisms expose subsidiaries to two different types of market forces. While internal market forces refer to competition among MNC units located in different countries, competition between an MNC unit and third companies in different markets is referred to as external market forces.

Internal Markets. After a major increase in the number of mergers and acquisitions in the $1980 \mathrm{~s}$, the inefficiencies of big organizations became notorious and a counter-movement took place which resulted in the deverticalization of many industrial conglomerates (Halal, 1994). Academia responded by crafting an emerging research field on new organizational forms which combine characteristics of markets and hierarchy, a challenge to Williamson's (1991) 'discrete structural alternatives'. Indeed, the idea of market-like governance forms within the MNC hierarchy goes back to earlier work. Hedlund (1986, p. 14), for instance, refining Perlmutters polycentric MNC, states that "transfer pricing based on market pricing" is increasingly used. Apart from the polycentric MNC, Market-like governance is also present in Hedlund's (1986) heterarchy were it coexists with hierarchical governance.

Deverticalization of firms into smaller business units and information technology encourages the infusion of markets into hierarchies, so-called internal hybrids, or of hierarchies into markets, so called external hybrids (Zenger \& Hesterly, 1997). We concentrate on the former, which are also known as internal markets. Several scholars cite reduced coordination costs, high-powered incentives which reward internal organizational units in compliance with their output, better means of measuring performance, superior flexibility, stronger intrapreneurial capabilities, among others, as the main advantages of internal markets (Birkinshaw, 1998; Halal, 1994). In particular, the use of hierarchical control and the price system in the same firm reduces the negative properties both of the hierarchy and of the price mechanism (Hennart, 1993).

Internal markets can be understood as a practice during which several business units compete for resources, orders or projects (Birkinshaw, 1998; Birkinshaw \& Fey, 2000) ${ }^{(1)}$. Thus, an internal market in an MNC R\&D network implies that product development units negotiate and sell their research and technical services to peer subsidiaries or to headquarters. In this sense, an internal market does not entail the complete recreation of market forces within a firm; rather, incentives and some market-like 
elements are introduced, such as competition, a price-system, bidding for projects, orders or investments (resources). This means that different product development units possess comparable capabilities and resources enabling them to compete for projects.

To follow, we examine two hypotheses based on two alternative assumptions. The first assumption is that product development units, the players in the internal market, possess similar resources and capabilities in the same high competence fields. In other words, these units own basically the same distinctive or niche competences of their MNC. The diffusion of knowledge and competences across the entire MNC R\&D network has been made increasingly feasible by knowledge management systems accessible MNC wide and by improved mechanisms of tacit knowledge transfer (Ernst \& Kim, 2002; Schulz \& Jobe, 2001).

Consequently, MNC product development units in different countries can compete for projects in these high competence fields. As soon as such a project has been assigned to a product development unit, the bulk of NPD work is likely to be carried out in-house because distinctive or niche competences are not considered subject to outsourcing (Narula, 2001). This means that internal market competition tends to increase innovative activities in-house. Thus, we hypothesize that

Hypothesis 2. The degree of internal market competition is positively related to in-house new product development.

The second assumption is that MNC subsidiaries, the players in the internal market, possess dissimilar resources and capabilities. Consequently, NPD projects are concentrated in centers of excellence or global subsidiary mandates, depending on the resources and capabilities required for project execution. This reasoning is based on center of excellence research (Andersson \& Forsgren, 2000; Birkinshaw \& Hood, 1998; Frost, Birkinshaw, \& Ensign, 2002; Holm \& Pedersen, 2000; Roth $\&$ Morrison, 1992). Hence, what can be shifted from one product development unit or one subsidiary to another are NPD projects or modules of projects which are mainly based on background or marginal competences. Not being of strategic importance to the MNC, the bulk of these projects or modules can be outsourced locally in order to reap cost, flexibility, lead-time or specialization advantages (see Section NPD Configuration in Foreign Subsidiaries on the expected benefits of NPD outsourcing). In other words, local outsourcing therefore contributes to increased NPD efficiency. In addition, outsourcing partners may contribute with complementary services and knowledge which may strengthen the unit's portfolio of technical services as well as the capacity to be offered to business units and subsidiaries abroad. As internal markets provide opportunities to offer product development services for peer subsidiaries, the focal product development unit has an incentive to increase its portfolio of services and make its services more competitive vis-à-vis peer product development units. Thus, we hypothesize that

Hypothesis 3. The degree of internal market competition is positively related to new product development outsourcing.

Global Decision-Making Autonomy. High headquarters control over its subsidiaries is reflected in low decision-making autonomy perceived by subsidiary management and vice-versa. The concept dates back to sociological work on control in organizations (Crozier, 1981) and has been incorporated by theoretical work on MNCs which associates different levels of autonomy with different organizational structures (Hedlund, 1986; Perlmutter, 1969). The concept of autonomy is also one of the most discussed in empirical literature on MNC subsidiaries (e.g. Frost et al., 2002; Ghoshal \& Bartlett, 1988; Gupta \& Govindarajan, 1994; Nobel \& Birkinshaw, 1998) and several literature reviews have dedicated special attention to it (e.g. Paterson \& Brock, 2002; Young \& Tavares, 2004).

The positive relationship between local decision-making autonomy (a subsidiary's autonomy regarding activities within its host country), and (product or process) innovation seems to be reasonably well established in literature (Ghoshal \& Bartlett, 1988; Holm \& Pedersen, 2000; Young \& Tavares, 2004). Conceptual work on global subsidiary mandates, such as 'product specialists' or 'strategic independent' subsidiaries has posited a positive relationship between global decision-making 
autonomy, i.e. autonomy regarding global markets (excluding the internal market of the MNC), and innovation (White \& Poynter, 1984). However, empirical evidence on this relationship is mixed (Birkinshaw, 1997; Roth \& Morrison, 1992); therefore, we revisit the relationship and attempt to integrate it into our conceptual framework.

Again, the following two hypotheses are based on two alternative assumptions. The first assumption supposes that the subsidiary carries out original NPD in areas of high technological competences, which Granstrand et al. (1997) call distinctive or niche competences. If a subsidiary possesses decision-making autonomy to develop and launch products on global markets (and not just on its local market), it faces a whole range of new market opportunities. These opportunities and the freedom to exploit them may expose the subsidiary and its product development department to a more diverse landscape of client requirements and competition. As a consequence, these opportunities may translate into powerful incentives to enhance innovative new product development activities. Given this, NPD is most likely to be carried out in-house for strategic reasons and to protect knowledge (Narula, 2001; Veugelers \& Cassiman, 1999). Hence, we posit that:

Hypothesis 4. The degree of global decision-making autonomy is positively related to in-house new product development.

The opposite assumption supposes that the subsidiary focuses on a sort of NPD in areas where high technological competences are not needed, for instance in low-tech areas. If headquarters has conceded global decision-making autonomy to the product development unit, the latter is exposed to incentives to exploit opportunities on the global market. As the unit is assumed to focus on the development of low-tech products for global markets, competitiveness is not so much based on innovation but on efficiency. As argued in section NPD Configuration in Foreign Subsidiaries, local outsourcing can contribute to efficiency gains, for instance, increasing capacity and sourcing generic technologies maintaining fixed costs constant, reducing costs reaping economies of scale, reducing development lead-time, among others. Assuming that the product development unit focuses on lowtech products, NPD mainly consists of generic, non-specific and routine activities (Veugelers \& Cassiman, 1999). Therefore, the unit will then primarily use NPD outsourcing, which is the preferred mode when NPD activities rely on lower levels of competences (Narula, 2001; Veugelers \& Cassiman, 1999). Thus, we hypothesize that:

Hypothesis 5. The degree of global decision-making autonomy is positively related to new product development outsourcing.

In sum, we posit that both concepts, internal markets and global decision-making autonomy, may have positive complementary effects on subsidiaries' in-house NPD and NPD outsourcing. This argument is represented by our conceptual model which encompasses all four concepts and the aforementioned five hypotheses (see Figure 1 above) $)^{(2)}$.

\section{METHOD}

\section{Sample}

The unit of analysis chosen for this study is a product development unit in a wholly foreign-owned MNC subsidiary. Since there was no database of reasonable size with MNC product development units available, we built our own sample frame based on secondary material, such as other (smaller) survey sample frames, a government database, databases from industry associations, information from newspapers and web research. All firms from the final sample frame were approached by different means (phone and e-mail). Due to the focus of this study on product development, we identified (by means of phone calls) the product development managers with responsibility for entire product families. These key informants were then directly contacted by e-mail and telephone in order to 
present the research, to convince them to take part in the survey and to check for their hierarchical position within the product development department. One additional criterion of respondent selection was that he/she should be in a position to keep direct working contact with other MNC units abroad. If the managers were responsible for several product families within their division, they were asked to limit their response to the product family most important to the subsidiary or division.

Altogether, 269 e-mails with hyperlinks to the server hosted questionnaires as well as self-executing questionnaire-files (in case corporate firewalls blocked web-access to questionnaires) were sent to our key informants. The researchers obtained 146 valid questionnaires, resulting in a response rate of 54\%. This response rate can be considered very high for web-surveys.

The profile of the sample can be described as follows: the most important countries of origin of the subsidiaries were the US (34.6\% of the sample), Germany (26.5\%), France (7.4\%), Japan (6.6\%), the UK $(5.2 \%)$ and Sweden (5.9\%). The main industrial sectors included in the survey were the automotive industry (36\%), electronic industry (36\%), machinery industry (12.5\%) and chemical industry $(5 \%)$. Some industries such as the pharmaceutical, agricultural, construction or service industry were excluded because of their unique characteristics or irrelevance in terms of industrial product development in Brazil. Testing for industry effects did not show statistically significant differences. The Brazilian subsidiaries were mainly concentrated in the federal states of São Paulo, Paraná, Rio Grande do Sul and Rio de Janeiro.

Two procedures for outlier detection were used. We considered extreme scores with more than three standard deviations off the mean as univariate outliers and deleted these observations. Multivariate outliers were detected using the procedures offered by Amos 5.0 (Build 5138), in particular, Mahalanobis distance and Mardias coefficient of multivariate kurtosis. As a result, sample size shrank to 136 observations.

\section{Measures}

In-house New Product Development [NPD]. In order to capture the extent to which a product development unit within a subsidiary carries out new product development activities, we asked the unit manager whether or not his unit carries out the following activities: new product designs, prototyping of new products and prototype tests. These indicators represent the main stages of the design-build-test cycle (Clark \& Fujimoto, 1991; Wheelwright \& Clark, 1992). A five-item Likert scale was used ranging from ' 1 - activity is never performed' through ' 5 - activity is always performed'. For reasons of parsimony, the last item (prototype tests) was eliminated from the overall model despite its high item validity. Overall scale reliability is acceptable (Cronbach alpha $=0.77$ ).

New Product Development Outsourcing. Outsourcing of new product development activities implies that the focal product development unit passes on specifications (development agreements) to a subcontractor who carries out new product design, builds prototypes or performs tests of the prototypes. Applying the same reasoning as above, three indicators which represent the main stages of the design-build-test cycle were used. Using the same Likert scale as above, respondents were asked to what extent their unit orders services of new product designs, prototyping of new products, prototype tests from local entities be they companies, technology centres or universities. The reliability for outsourcing of design and prototyping is also quite reasonable (Cronbach alpha $=0.68$ for the two indicator based construct). Although alpha coefficients above 0.7 are recommendable, reliabilities around 0.6 suffice for initial stages of basic research (Nunally, 1967 as cited in Churchill, 1979, p. 68).

Internal market. Internal competition was operationalized using three items proposed by the Birkinshaw and Fey (2000) case study research on internal markets in R\&D organizations. The measures had to be adapted to the context of subsidiary research, since the original questionnaire items were applied to headquarters staff. A five item scale (1 - fully disagree through $\mathbf{5}$ - fully agree) was applied to statements such as competition for product development projects among PDUs in different countries, market-like bidding for projects and commercialization of product development services to 
other units. The reasoning is as follows: if key informants agree that there is competition among units, bidding for projects and selling of product development related services to other units and subsidiaries occurs in the MNC, then they perceive essential characteristics of an internal market-like organizational mechanism. Reliability for a two item construct was deemed acceptable for early stage construct development $($ Cronbach alpha $=0.67)$.

Global decision-making autonomy. We operationalized the global decision-making autonomy of the PDU using two items: the decision to initiate new product development projects for the global market and the decision to launch these projects on the global market. This construct is inspired by Foss (2003, p. 336), Nobel and Birkinshaw (1998) and Andersson and Forsgren (1996), who proposed similar items. A five-point Likert scale was used with ' 1 - Headquarters decides alone' through '5 this subsidiary decides alone'. The scale reliability was high $($ Cronbach alpha $=0.89)$.

\section{Data Analysis}

We used AMOS 5.0 software with the maximum likelihood algorithm to fit the hypothesized structural model (Figure 2). Altogether, 30 parameters were freely estimated (the others were fixed). Considering the sample size of 136 observations, the ratio between freely estimable parameters and observations is 1:4.5 which is slightly below the recommended minimum benchmark of 1:5. However, maximum likelihood modeling 'is justifiable when the sample size minus the number of parameters to be estimated is greater than 50' (Bagozzi, 1981, p. 380) or as soon as sample size exceeds 100 observations. Fixing three parameters of the model with standardized estimates close to ' 0 ' lifted the ratio above the benchmark of ' $1: 5$ ' while all other parameters remain close to the original estimates.

\section{RESULTS}

Table 1 provides correlations for all the indicators used in this study.

Table 1

\section{Correlations}

\begin{tabular}{lcccccccc}
\hline Observed variables & $\mathbf{1}$ & $\mathbf{2}$ & $\mathbf{3}$ & $\mathbf{4}$ & $\mathbf{5}$ & $\mathbf{6}$ & $\mathbf{7}$ & $\mathbf{8}$ \\
\hline 1 In-house design (DESI) & 1 & & & & & & & \\
2 In-house prototyping (PROTI) & $0.63^{* *}$ & 1 & & & & & & \\
3 Design outsourcing (DESO) & $0.19^{*}$ & $0.20^{*}$ & 1 & & & & & \\
4 Prototype outsourcing PROTO) & 0.16 & $0.17^{*}$ & $0.52^{* *}$ & 1 & & & & \\
5 Global project initiation NPDEX) & $0.25^{* *}$ & $0.29^{* *}$ & 0.03 & -0.03 & 1 & & & \\
6 Global product launch(LAUNEX) & $0.19^{*}$ & $0.30^{* *}$ & 0.02 & 0.00 & $0.81^{* *}$ & 1 & & \\
7 Internal competition (COMPET) & 0.00 & -0.05 & 0.14 & $0.17^{*}$ & -0.10 & -0.06 & 1 & \\
8 Bidding process (INTMKT) & 0.09 & -0.05 & 0.15 & $0.18^{*}$ & -0.01 & -0.04 & $0.39^{* *}$ & 1 \\
Control variables & & & & & & & & \\
Electronics industry & 0.07 & 0.14 & 0.15 & 0.10 & -0.02 & -0.08 & $0.173 *$ & 0.05 \\
Automotive industry & -0.15 & -0.03 & -0.01 & 0.09 & -0.03 & 0.11 & -0.09 & -0.03 \\
\hline Note: * significant at $0.05 \quad$ ** significant at 0.01. & & & &
\end{tabular}




\section{Measurement Model}

The reliabilities (Cronbach alpha) of all four constructs are well above 0.6 and therefore acceptable (see Table 2). Following Fornell and Larcker (1981), we calculated composite reliability and average variance extracted (AVE). None of the composite reliabilities $\left(6^{\text {th }}\right.$ column of Table 2$)$ fell below the benchmark of 0.6 (Bagozzi \& Yi, 1988). The average variance extracted $\left(7^{\text {th }}\right.$ column of Table 2 ) measures the amount of variance captured by the construct compared to the variance due to measurement error (Fornell \& Larcker, 1981, p. 45). Though one AVE dropped slightly below the recommended benchmark of 0.5 , we decided to maintain the internal market construct, since other measures were acceptable (similar factor loadings and all of them above $0.5, \mathrm{R}^{2}$ above 0.4 , significant critical values, i.e. above 1.96 indicating that factor loadings were significant at least at the 0.05 level). Altogether, data suggest that the four constructs exhibit acceptable levels of reliability.

Table 2

\section{Constructs and Reliabilities}

\begin{tabular}{lccccccc}
\hline Construct & Indicators & Factor Loading & Error terms & C.R. & $\mathbf{R}^{\mathbf{2}}$ & Reliability & AVE \\
\hline Internal Market & COMPET & 0.64 & 0.59 & - & 0.41 & 0.60 & 0.43 \\
& INTMKT & 0.67 & 0.55 & 2.269 & 0.45 & & \\
Global Autonomy & NPDEX & 0.85 & 0.29 & 4.810 & 0.71 & 0.90 & 0.81 \\
& LAUNEX & 0.95 & 0.09 & - & 0.91 & & \\
In-house NPD & PROTI & 0.83 & 0.31 & - & 0.69 & 0.77 & 0.63 \\
& DESI & 0.75 & 0.44 & 4.438 & 0.56 & & \\
NPD outsourcing & PROTO & 0.72 & 0.48 & 3.595 & 0.52 & 0.68 & 0.52 \\
& DESO & 0.72 & 0.48 & - & 0.52 & & \\
\hline
\end{tabular}

The correlations between constructs and their indicators (Table 3) show satisfactory discriminant validity, as correlations between constructs and their defining indicators are significant and high while correlations between indicators and the remaining constructs are low and non-significant. 
Table 3

Discriminant Validity - Correlations between Constructs and Indicators

\begin{tabular}{lcccc}
\hline & $\begin{array}{c}\text { Global } \\
\text { Autonomy }\end{array}$ & $\begin{array}{c}\text { In-house } \\
\text { NPD }\end{array}$ & $\begin{array}{c}\text { NPD } \\
\text { Outsourcing }\end{array}$ & $\begin{array}{c}\text { Internal } \\
\text { Market }\end{array}$ \\
\hline In-house Design (DESI) & 0.11 & $0.90^{* *}$ & 0.09 & 0.07 \\
In-house Prototyping (PROTI) & 0.13 & $0.87^{* *}$ & 0.15 & -0.10 \\
Design outsourcing (DESO) & 0.01 & 0.13 & $0.86^{* *}$ & 0.09 \\
Prototyping outsourcing (PROTO) & -0.03 & 0.09 & $0.86^{* *}$ & 0.12 \\
Global Autonomy/project initiation (NPDEX) & $0.94^{* *}$ & 0.15 & -0.02 & -0.03 \\
Global Autonomy/product launch (LAUNEX) & $0.95^{* *}$ & 0.10 & 0.00 & -0.03 \\
Competition for PD projects (COMPET) & -0.05 & -0.02 & 0.09 & $0.83^{* *}$ \\
Bidding for NPD projects (INTMKT) & -0.01 & 0.01 & 0.11 & $0.84^{* *}$ \\
Global Autonomy & 1 & $0.214^{*}$ & -0.019 & -0.076 \\
In-house NPD & $0.214^{*}$ & 1 & $0.230^{* *}$ & 0.010 \\
NPD Outsourcing & -0.019 & $0.230^{* *}$ & 1 & $0.174^{*}$ \\
Internal Markets & -0.076 & 0.010 & $0.174^{*}$ & 1 \\
\hline
\end{tabular}

Note. $* *$ significant at $0.01 ; *$ significant at 0.05 .

\section{Structural Model}

The fit indices provide strong support for the whole structural model. The chi-square $\left(\chi^{2}=8.535\right)$ statistic for the model is low and insignificant $(\mathrm{p}=0.86)$, suggesting that the covariance matrix of the eight observed indicators fits well the hypothesized structural model (Figure 2). Adjusting for degrees of freedom $(\mathrm{DF}=14)$, the ratio $\chi^{2} / \mathrm{df}(0.61)$ drops well below the maximum value of 3 recommended by Kline (1998, p. 128), indicating a good model fit.

The incremental fit indices, the normed fit index [NFI] and the comparative fit index [CFI] show values well above the minimum benchmark of 0.9 , suggesting that the model fit is at least $90 \%$ better than the null model. The CFI takes the special characteristics of small samples into account.

The root mean square error of approximation (RMSEA) indicates very good fit and there is a probability of $90 \%$ that the RMSEA value falls between 0.0 and 0.045 .

Hoelter's critical $\mathrm{N}$ indicates the largest sample size for which a model would be correct; thus it focuses directly on the adequacy of sample size (Byrne, 2001). A critical N of 375 at the 0.05 significance level implies that the present model would be correct with a sample size up to $n=375$.

Additionally, we checked the standardized residual covariances on the AMOS output table. According to Joreskog and Sorbom (1988, as cited in Byrne, 2001, p. 89), standardized residual covariances should not exceed 2.58. As no residual was greater than 1.175, Joreskog and Sorbom's criterion is fulfilled. Modification indices are low and do not exceed 4.2; the implied parameter change is also low (0.11), which is why no action was taken.

We also examined whether alternative relationships between the two independent variables, internal market and global decision-making autonomy, and the two dependent variables, in-house NPD and NPD outsourcing, would lead to an improvement of fit. For this purpose, two alternative models were estimated. In Model II, we set the parameter between internal market and NPD outsourcing at ' 0 ' and in Model III we set the parameter between global decision-making autonomy and in-house NPD at ' 0 '. 
Although both alternative models would not be rejected by fit statistics, they are considerably weaker than the unrestricted Model I as chi-square $\left(\chi^{2}\right)$ rises from 8.535 to 15.560 and 17.691 respectively. Therefore, only the original model should be maintained.

As for hypothesis tests, we examined the critical values and path coefficients between the four latent constructs. Critical values above 1.96 indicate statistical significance at the 0.05 level, and critical values above 2.58 indicate statistical significance at the 0.01 level. Three of our five hypotheses were supported (see Figure 2).

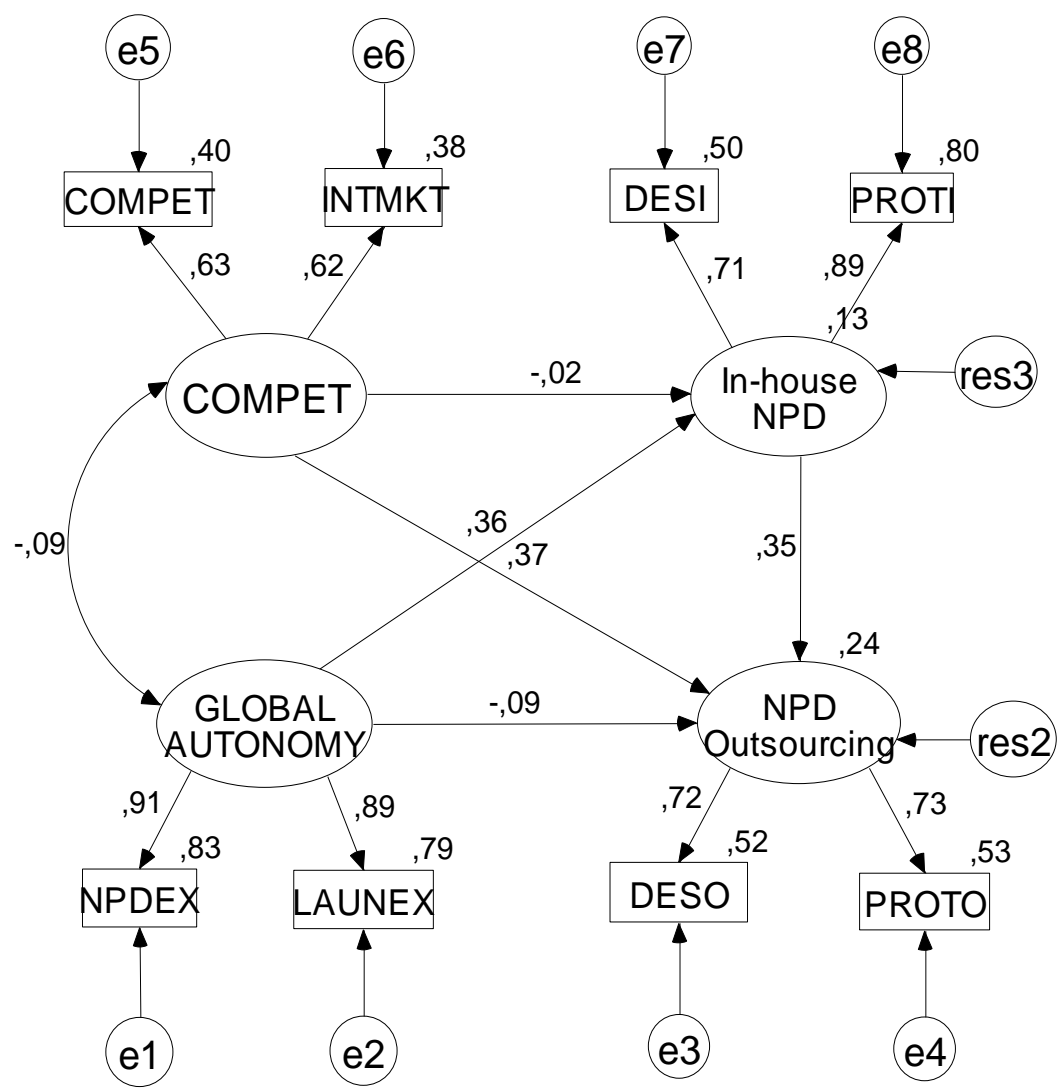

Figure 2: Path Model

The relationship between in-house NPD and NPD outsourcing is positive (path coefficient $=0.39$ ) and significant (critical value $=2.796$ ), which supports hypothesis $\mathrm{H} 1$.

Internal Market has no significant impact on in-house NPD (path coefficient $=-0.009$, critical value $=-0.075)$, which rejects hypothesis $\mathrm{H} 2$. However, internal market has a significant positive relationship with NPD outsourcing, with a path coefficient of 0.36 and a critical value of 2.237. Hence, there is support for hypothesis $\mathrm{H} 3$.

There is a significant positive relationship between global decision-making autonomy and in-house NPD (path coefficient $=0.31$; critical value $=2.849$ ), thereby supporting hypothesis $\mathrm{H} 4$. The fifth hypothesis H5 posits a positive relationship between global decision-making autonomy and NPD outsourcing. This hypothesis was not supported (path coefficient $=-0.09$; critical value of -0.883 ). 


\section{DISCUSSION}

This research has examined the question of how MNC coordination mechanisms influence subsidiaries' new product development [NPD] activities. More specifically, how two essential coordination mechanisms, global decision-making autonomy and internal markets, influence NPD intensity, exposing product development units to internal and external global market forces. Evolutionary theory suggests that market competition favorably influences organizational and technological learning in general, and innovation in particular. However, it has yet to be empirically examined how MNCs can utilize coordination mechanisms in order to expose their product development units both to internal and external competition and how this influences the NPD activities of the latter. This study fills this gap in that it proposes a model which hypothesizes the impact of two coordination mechanisms, a) decision-making autonomy regarding product development for global markets and b) internal markets on the intensity of in-house NPD and NPD outsourcing. Our results suggest that exposure to internal markets increases the intensity of NPD outsourcing, which in turn is positively related to in-house NPD. Furthermore, the findings indicate that exposure to global markets (conceding autonomy) directly increases the intensity of new product development.

\section{Contributions}

Therefore, this paper makes several contributions to the literature on MNC coordination mechanisms and to the development of subsidiary product development.

First of all, we extend literature on headquarters-subsidiary and subsidiary-subsidiary coordination mechanisms by testing a model which integrates the construct of internal markets along with the construct of global decision-making autonomy. Both can be considered as formal coordination mechanisms, although internal markets may have both formal or informal qualities depending on the degree to which they are put into practice and to whether headquarters has made its use explicit or not. Adding this dimension to the coordination mechanisms stream of literature is important because the intrusion of market-like elements into the hierarchy seems to become an increasingly frequent practice which has been underscored by this research.

Second, we extend subsidiary level literature on innovative activities by differentiating between inhouse NPD and NPD outsourcing. This is important because firms may leverage their NPD activities combining in-house and outsourced NPD activities. Hypotheses H2, H3, H4 and H5 were developed to test which coordination mechanism is more likely to influence in-house NPD or NPD outsourcing. In fact, our model suggests that the increase of in-house NPD is influenced by global autonomy while NPD outsourcing is influenced by internal markets. How can these finding be explained?

A possible explanation is that PDUs react differently to global internal and external market opportunities. As follows from our literature review, internal market opportunities can be characterized as new product development according to specifications defined by other MNC units. Thus, performance is likely to be measured in efficiency terms (costs, quality, time-to-market, etc.). Outsourcing of technological services may contribute to efficiency, since fixed costs can be kept stable while capacity becomes enhanced. Outsourcing may also permit the yielding of specialization advantages and thus contribute to economies of scale and quality. Moreover, outsourcing may speedup product development because project stages can be carried out in parallel by different entities, thus reducing overall project lead time.

As for the direct effect of global autonomy on in-house NPD, the conquest of new markets beyond the host country implies more diverse and demanding client requirements. Thus, performance is likely to be evaluated in terms of effectiveness; this is the innovativeness of new products launched. However, outsourcing does not necessarily favor the development and market introduction of new pathbreaking products (Kessler, Bierly, \& Gopalakrishnan, 2000). Similarly, whereas strategic and market relevant knowledge tends to be kept in-house, less strategic routine work is likely to be 
outsourced (Narula, 2001). Therefore, global market opportunities may translate directly into an increase of strategically relevant in-house rather than NPD outsourcing.

The positive relationship between in-house NPD and NPD outsourcing now makes even more sense, as internal markets may result in a re-distribution of the NPD related activities carried out internally and externally: outsourcing of less strategically relevant and activities with a high impact on NPD efficiency may free capacity for an increase of strategically relevant, more innovative NPD in-house, which explains our first hypothesis.

Another related point is the time horizon of NPD activities. The short-term orientation of internal market opportunities compared to global market opportunities may provide a further explanation of our empirical findings. Internal opportunities may arise when other MNC units work at the upper limit of capacity. Therefore, it would be wise to deal with these projects in a flexible manner, i.e., without increasing fixed costs, which favors NPD outsourcing. Even so, exploiting global market opportunities may imply a more proactive and long-term management orientation, which would justify maintaining projects in-house.

Third, our findings also refine the literature on subsidiary development. Birkinshaw and Hood (1998, p. 787) claim that "competitive internal resource allocation ... provides a motivation for them (subsidiaries) to continually upgrade their capabilities". Furthermore, they propose that a competitive internal resource allocation mechanism positively influences the likelihood that a subsidiary management takes initiatives to enlarge or reinforce its charter, i.e., its temporary market or product responsibility. The same rationale applies to the decentralization of decision-making, which is also seen as positively related to subsidiary capability building and charter enlargement or reinforcement. Though not exactly focused on product development, Birkinshaw and Hood's (1998) theoretical propositions are compatible with our empirical findings, because an increase in NPD can be regarded as a manifestation of subsidiary capability building and as a prerequisite for charter enlargement or reinforcement.

These possibly stimulating effects of competitive resource allocation mechanisms on subsidiary development may even be more effective when subsidiaries in emerging markets, such as Brazil, Russia, India or China, are concerned. Low or medium cost advantages in these countries may improve the competitiveness of subsidiaries located in emerging markets vis-à-vis their peers in industrialized countries. Moreover, similar to emerging market multinationals that leverage their local capabilities abroad, MNC subsidiaries in emerging markets may also have developed efficiency advantages based on process and project management excellence while dealing with often adverse and volatile local business conditions (Ramamurti, 2009). In short, subsidiaries located in emerging markets are likely to enjoy a set of country specific and firm specific advantages that may provide them with an edge over their peers in industrialized countries when multinationals use competitive resource and project allocation mechanisms such as internal market competition.

Fourth, the study contributes in that it operationalizes the internal market construct in a large scale survey which has not been done previously. Thus, the study fills an important void, i.e. the empirical test of a construct related to subsidiary development and MNC coordination mechanism literature.

\section{Managerial Implications}

If different coordination mechanisms indeed expose subsidiaries to internal and external market forces, then subsidiary management should proactively organize its product development unit for rising market opportunities. When MNCs use internal markets as coordination mechanisms, then subsidiary management should prepare its product development unit for arising internal market opportunities by identifying, evaluating and establishing business relationships with potential outsourcing partners. In response to increasing or decreasing use of internal market coordination, such a local outsourcing network could be relied on in a flexible way. 
Likewise, when MNCs use global market decision-making autonomy as a coordination mechanism, subsidiary management should prepare its product development unit by developing technological capabilities that enable it to take advantage of upcoming opportunities in global markets. This is not new in itself, but may appear in new light when considered together with the relationship between internal market and outsourcing.

The substantial relationship between NPD outsourcing and in-house NPD, may imply that subsidiary management needs to develop a methodology for smoothly and efficiently combining in-house NPD and external (outsourced) NPD capacities, particularly when exposed to both internal and external market forces.

\section{Limitations and Future Research}

This research has tested a model using a country-specific data-set. Despite the fact that construct operationalization has not been linked to country-specific characteristics, further research should ensure the generalization of the model to other contexts, both low cost and high cost countries. This is important as the substantial effect of internal market coordination on NPD outsourcing may be due to the particular cost advantages of a medium cost country like Brazil vis-à-vis high cost countries where competing peer subsidiaries are located. Future research might also consider settings with more diverse industries (high technology vs. low technology) and control for technological capabilities.

Due to limits imposed by sample-size, only two coordination mechanisms were included in our model. Though both coordination mechanisms may be of primary relevance as they represent two main dimensions of organizational economics (market and hierarchy), future research should advance studying interaction effects with other formal and informal coordination mechanisms. Thus, theory development about coordination mechanisms would benefit from a more comprehensive modeling approach. A further step in future research could then add host country related factors and thus provide us with a more comprehensive model.

\section{NOTES}

\footnotetext{
${ }^{1}$ It is important to note that the concept of internal markets is different from the concept of intra-firm competition. The latter refers to a state in which two or more organizational units undertake duplicate activities, such as parallel development of competing solutions for the same problem or the coexistence of two or more products and brands targeting the same market (Birkinshaw, 2001; Birkinshaw \& Lingblad, 2001; Birkinshaw \& Lingblad, 2005; Galunic, D. C., \& Eisenhardt, K. M. (1996). The evolution of intracorporate domains: divisional charter losses in high-technology, multidivisional corporations. Organization Science, 7(3), 255-282).

\begin{abstract}
${ }^{2}$ A hypothesis about a possible relationship between the constructs Global Autonomy and Internal Market Coordination was not included in the model for two reasons: first, the constructs cover different sets of relationships: while global autonomy refers to the decision-making autonomy of a specific subsidiary (here: the Brazilian unit) conceded by headquarters, internal market competition refers to the relationships among several (more than two) MNC units that compete for resources and projects. Second, the author is not aware of any convincing theoretical reasoning that could be used to support a relationship between both constructs.
\end{abstract}

\section{REFERENCES}

Andersson, U., \& Forsgren, M. (1996). Subsidiary embeddedness and control in the multinational corporation. International business review, 5(5), 487-508.

Andersson, U., \& Forsgren, M. (2000). In search of centre of excellence: network embeddedness and subsidiary roles in multinational companies. Management International Review, 40(4), 329-350. 
Bagozzi, R. P. (1981). Evaluating structural equation models with unobservable variables and measurement error: a comment. Journal of Marketing Research, 18(3), 375-381.

Bagozzi, R. P., \& Yi, Y. (1988). On the evaluation of structural equation models. Journal of the Academy of Marketing Science, 16(1), 74-95.

Bartlett, C., \& Ghoshal, S. (1986). Tap your subsidiaries for global reach. Harvard Business Review, $4(6), 87-94$.

Bartlett, C., \& Ghoshal, S. (1989). Managing across borders: the transnational solution. Boston: Harvard Business School Press.

Birkinshaw, J. (1996). How multinational subsidiary mandates are gained and lost. Journal of International Business Studies, 27(3), 467-496.

Birkinshaw, J. (1997). Entrepreneurship in multinational corporations: the characteristics of subsidiary initiatives. Strategic Management Journal, 18(3), 207-229.

Birkinshaw, J. (1998). Corporate entrepreneurship in network organizations: how subsidiary initiative drives internal market efficiency. European Management Journal, 16(3), 355-364.

Birkinshaw, J. (2001). Strategies for managing internal competition. California Management Review, 44(1), 21-39.

Birkinshaw, J., \& Fey, C. (2000). Building an internal market system: insights from five R\&D organizations. In J. Birkinshaw \& P. Hagstrom (Eds.). The flexible firm: capability management in network organizations (pp. 149-175). Oxford: Oxford University Press.

Birkinshaw, J., \& Hood, N. (1998). Multinational subsidiary evolution: capability and charter change in foreign-owned subsidiary companies. The Academy of Management Review, 23(4), 773-796.

Birkinshaw, J., \& Lingblad, M. (2001). An evolutionary theory of intra-organisational competition. Retrieved April 22, 2009, from http://citeseerx.ist.psu.edu/viewdoc/download?doi=10.1.1.133.5371\&rep=rep1\&type=pdf

Birkinshaw, J., \& Lingblad, M. (2005). Intra-firm competition and charter evolution in the multibusiness firm. Organization Science, 16(6), 674-686.

Bouquet, C., \& Birkinshaw, J. (2008). Weight versus voice: how foreign subsidiaries gain attention from corporate headquarters. Academy of Management Journal, 51(3), 577-601.

Bouquet, C., Morrison, A., \& Birkinshaw, J. (2009). International attention and multinational enterprise performance. Journal of International Business Studies, 40(1), 108-131.

Byrne, B. (2001). Structural equation modeling with Amos: basic concepts, applications, and programming. Mahwah: Lawrence Erlbaum Associates Publishers.

Churchill, G. (1979). A paradigm for developing better measures of marketing constructs. Journal of Marketing Research, 16, 64-73.

Clark, K. B., \& Fujimoto, T. (1991). Product development performance: strategy, organisation and management in the world auto industry. Boston, Mass: Harvard Business School Press.

Croisier, B. (1998). The governance of external research: empirical test of some transaction-cost related factors. $R \& D$ Management, 28(4), 289-298.

Crozier, M. (1981). O fenômeno burocrático. Brasília: Editora Universidade de Brasília. (Obra original publicada em 1963). 
Ernst, D., \& Kim, L. (2002). Global production networks, knowledge diffusion, and local capability formation. Research Policy, 31(1), 1417-1429.

Espino-Rodríguez, T., \& Padrón-Robaina, V. (2006). A review of outsourcing from the resource-based view of the firm. International Journal of Management Reviews, 8(1), 49-70.

Fischer, W., \& Behrman, J. (1979). The coordination of foreign R\&D activities by transnational corporations. Journal of International Business Studies, 10(3), 28-35.

Fornell, C., \& Larcker, D. (1981). Evaluating structural equation models with unobservable variables and measurement error. Journal of Marketing Research, 18(1), 39-50.

Foss, N. (2003). Selective intervention and internal hybrids: interpreting and learning from the rise and decline of the oticon spaghetti organization. Organization Science, 14(3), 331-349.

Foss, N., \& Pedersen, T. (2002). Transferring knowledge in MNCs The role of sources of subsidiary knowledge and organizational context. Journal of International Management, 8(1), 49-67.

Frost, T., Birkinshaw, J., \& Ensign, P. (2002). Centers of excellence in multinational corporations. Strategic Management Journal, 23(11), 997-1018.

Frost, T. S., \& Zhou, C. (2005). R\&D co-practice and 'reverse' knowledge integration in multinational firms. Journal of International Business Studies, 36(6), 676-687.

Ghoshal, S., \& Bartlett, C. (1988). Creation, adoption and diffusion of innovations by subsidiaries of multinational companies. Journal of International Business Studies, 19, 365-388.

Ghoshal, S., \& Nohria, N. (1993). Horses for courses: organizational forms for multinational corporations. Sloan Management Review, 34, 23-35.

Granstrand, O., Patel, P., \& Pavitt, K. (1997). Multi-technology corporations: why they have "distributed" rather than "distinctive core" competencies. California Management Review, $39(4), 8-25$.

Gupta, A., \& Govindarajan, V. (1991). Knowledge flows and the structure of control within multinational corporations. Academy of Management Review, 16(4), 768-792.

Gupta, A., \& Govindarajan, V. (1994). Organizing for knowledge flows within MNCs. International Business Review, 3(4), 443-457.

Halal, W. (1994). From hierarchy to enterprise: internal markets are the new foundation of management. The Academy of Management Executive, 8(4), 69-83.

Hedlund, G. (1986). The hypermodern MNC - a heterarchy? Human Resource Management, 25(1), 9-35.

Hennart, J. F. (1993). The swollen middle: a mix of market and hierarchy. Organization Science, 4(4), 529-547.

Holm, U., \& Pedersen, T. (2000). The emergence and impact of MNC centers of excellence: a subsidiary perspective. London: McMillan Press.

Jarillo, J. C., \& Martinez, J. (1990). Different roles for subsidiaries: the case of multinational corporations in Spain. Strategic Management Journal, 11(7), 501-512.

Kessler, E. H., Bierly, P. E., \& Gopalakrishnan, S. (2000). Internal and external learning in new product development: effects on speed, costs and competitive advantage. $R \& D$ Management, 30(3), 213-233.

Kline, R. (1998). Principles and practice of structural equation modeling. New York: Guilford Press. 
Kurokawa, S., Iwata, S., \& Roberts, E. (2007). Global R\&D activities of Japanese MNCs in the US: a triangulation approach. Research Policy, 36(1), 3-36.

Martinez, J., \& Jarillo, J. C. (1991). Coordination demands of international strategies. Journal of International Business Studies, 22(3), 429-444.

Monteiro, L. F., Arvidsson, N., \& Birkinshaw, J. (2008). Knowledge flows within multinational corporations: explaining subsidiary isolation and its performance implications. Organization Science, 19(1), 90-107.

Narula, R. (2001). Choosing between internal and non-internal R\&D activities: some technological and economic factors. Technology Analysis \& Strategic Management, 13(3), 365-387.

Nobel, R., \& Birkinshaw, J. (1998). Innovation in multinational corporations: control and communication patterns in international R\&D operations. Strategic Management Journal, 19(5), 479-496.

Paterson, S. L., \& Brock, D. M. (2002). The development of subsidiary management research: review and theoretical analysis. International Business Review, 11(2), 139-163.

Perlmutter, H. (1969). The tortuous evolution of the multinational corporation. Columbia Journal of World Business, 4(1), 9-18.

Ramamurti, R. (2009). What have we learned EMNEs? In R. Ramamurti \& J. Singh (Eds.). Emerging multinationals in emerging markets (Chap. 13, pp. 399-426). Cambridge: Cambridge University Press.

Roth, K., \& Morrison, A. J. (1992). Implementing global strategy: characteristics of global subsidiary mandates. Journal of International Business Studies, 23(4), 715-736.

Sanna-Randaccio, F., \& Veugelers, R. (2007). Multinational knowledge spillovers with centralized versus decentralized R\&D: a game theoretic approach. Journal of International Business Studies, 38(1), 47-63.

Schulz, M., \& Jobe, L. (2001). Codification and tacitness as knowledge management strategies an empirical exploration. Journal of High Technology Management Research, 12(1), 139-165.

Venaik, S., Midgley, D. F., \& Devinney, T. M. (2005). Dual paths to performance: the impact of global pressures on MNC subsidiary conduct and performance. Journal of International Business Studies, 36(6), 655-675.

Veugelers, R. (1997). Internal R\&D expenditures and external technology sourcing. Research Policy, 26(3), 303-315.

Veugelers, R., \& Cassiman, B. (1999). Make and buy in innovation strategies: evidence from Belgian manufacturing firms. Research Policy, 28(1), 63-80.

Wheelwright, S., \& Clark, K. (1992). Revolutionizing product development: quantum leaps in speed, efficiency and quality. New York: Free Press.

White, R., \& Poynter, T. (1984). Strategies for foreign-owned subsidiaries in Canada. Business Quarterly, 49(2), 59-70.

Williamson, O. E. (1991). Comparative economic organization: the analysis of discrete structural alternatives. Administrative Science quarterly, 36(2), 269-296. 
Young, S., \& Tavares, A. T. (2004). Centralization and autonomy: back to the future. International Business Review, 13(2), 215-237.

Zenger, T., \& Hesterly, W. (1997). The disaggregation of corporations: selective intervention, highpowered incentives, and molecular units. Organization Science, 8(3), 209-222. 